\title{
Die riglyn vir Christen etiek: Galasiërs 6:2 onder die loep
}

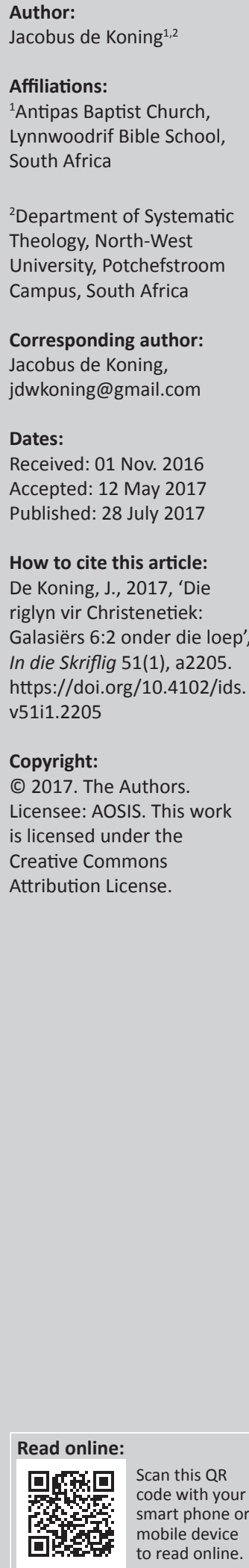

\begin{abstract}
The guideline for Christian ethics: Galatians 6:2 under scrutiny. In this article, the following question is addressed: What is the guideline for Christian ethics under the New Testament dispensation? The article reasons that the Torah can no longer be the guideline for Christian ethics. Galatians 6:2 is scrutinised as the focal point for this reflection. This is done with reference to the Jesus tradition in Paul, the rabbinic tradition and Matthew 5, as well as the use of Galatians 6:11-18 as hermeneutical key to the understanding of Galatians. It is clearly shown that Galatians 6:2 teaches that Christ the crucified now replaces the entire Torah. Therefore it is not

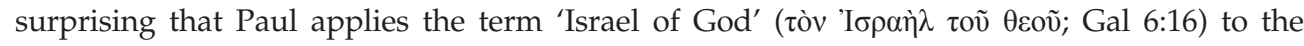
community of those who are in Christ and wherein the Torah finds its fulfilment. This insight from Galatians 6 is then used as the point of departure for remarks about ethics and ethical preaching which should characterise 'being church' for reformed Christians in general and specifically in South Africa. In this article ethics under the Old Testament dispensation is explored as well as the difference that came into force under the New Testament dispensation. For the church in South Africa who finds herself in a society plagued by racial hatred, xenophobia and suspicion, living the law of Christ is non-negotiable if one wants to see healing in this country. Accordingly, an adjustment in the liturgy of some mainstream churches in South Africa is a given when the law of Christ becomes the guideline for the Christian's ethical behaviour.
\end{abstract}

\section{Inleiding}

Die drie susterskerke sowel as sekere onafhanklike gemeentes en die Church of England in SuidAfrika se wortels lê stewig in die regsinnige kerk van die vroegste tye en die Protestantse teologie van die sestiende eeu geanker. Die betoog wat volg, is veral op hiérdie gereformeerdes in SuidAfrika gerig, maar wil ook 'n problematiek in die groter gereformeerde wêreld hanteer.

Vanaf die vroegste tye tot op hede aanvaar die regsinnige Christelike kerk die Tora as deel van die Bybel en daarom, op een of ander wyse, as gesaghebbend en bindend. Baie vroeg in die geskiedenis het die kerk besef dat die Tora nie sonder meer direk deur die Christelike kerk in die geheel oorgeneem kan word nie. Vandaar die onderskeidings wat reeds van die vroegste tye af binne die Tora gemaak is. 'n Kenmerkende verdeling, waarskynlik die mees populêre by die kerkvaders, is die verdeling van die Tora in twee dele, naamlik die morele gebooie wat deur Christus behou en uitgebrei is en die seremoniële wat met Christus tot 'n einde kom (Irenaeus 2006: Haer. 16.4-5).

Sekerlik die bekendste onderskeiding is die driedeling in morele, seremoniële en burgerlike wetgewing wat reeds by Thomas van Aquino voorkom (1947: Summa Theologica. 1a.2ae.99,35).

Die Hervormers neem hierdie driedeling oor. Die seremoniële wet is gesien as 'n onderwysing van die Jode waarmee dit die Here behaag om sy volk in hulle kinderskoene te oefen totdat die volheid van die tyd aanbreek. Die burgerlike wet is beskou as gegee vir staatsreëling, met bepaalde voorskrifte van billikheid en geregtigheid sodat mense daarvolgens sonder skade en rustig teenoor mekaar kon optree (Calvyn 1948: Inst. 4.20.14,15).

Die sedewet is as die ware en ewige reël van geregtigheid gesien wat vir mense van alle volkere en tye voorgeskryf is. Calvyn gebruik die sedewet in hierdie sin en verdeel dit verder, op grond van die funksies, in drie dele:

- dit dryf ons in sy veroordeling na Christus;

- dit bedwing die goddelose; en

- dit lei gelowiges dieper in die kennis van die wil van God en spoor hulle tot geregtigheid aan (Calvyn 1948: Inst. 2.7.6). 
Hierdie gebruik deur Calvyn vind onder andere in die Heidelbergse Kategismus. (Sondag 2-4 en Sondag 32-52) asook die Westminster Confession (par. 19) neerslag.

In die Protestantse teologie word die volgende volgorde van die gebruik van die sedewet dus gemene taal:

- die usus politicus (eerste gebruik), of burgerlike gebruik van die sedewet in die staat en die gemeenskap;

- die usus elenchticus (tweede gebruik), of evangeliese gebruik van die wet as leermeester van die sonde in die ervaring van bekering tot God; en

- die usus didacticus, of normativus (derde gebruik), of didaktiese gebruik van die wet as die reël vir dankbare gehoorsaamheid aan God (Berkhof 1988:613-615).

Dit is egter binne die sogenaamde federale teologie ${ }^{1}$ wat na die Reformasie op die voorgrond getree het dat hierdie gebruik van die sedewet binne ' $n$ problematiese raamwerk gelaas word. J.B. Torrance (1994:19-33) toon aan dat federale teoloë ná Calvyn met hulle handhawing van 'n werkverbond, hulself onteenseglik in ' $n$ posisie bevind waarin die wet voorrang bo genade het. Hierdie gevolgtrekking word gemaak aangesien die wet van God wat by Sinai aan Israel gegee is in wese die herbevestiging is van die eise van die werkverbond. Die bedoeling van die genadeverbond is ook dat daar aan die eise van die werkverbond voldoen moet word. Aangesien die sondaar dit nie self kan doen nie, kom Christus om dit in sy plek te doen. Die wet word dus as die grondstruktuur van die verhouding tussen God en die mens verstaan. Torrance probeer aandui dat dit egter nie die geval by Calvyn is nie, aangesien hy nie met' $n$ werkverbond handel nie. Teenoor die skema van wet en genade van latere federale teoloë, werk Calvyn met'n genade en wet-skema.

Aangesien die invloed van federale teologie via die belydenisskrifte steeds sterk in die gereformeerde wêreld figureer, moet hierdie teologiese rigting as die 'opponent' in hierdie artikel gesien word.

Met hierdie teologiese agtergrond is dit natuurlik vanselfsprekend dat die gebruik van die lees van die Dekaloog aan die begin van elke erediens ' $n$ instelling is wat selde in sekere kerke onder die invloed van federalisme bevraagteken word. Dit is insiggewend dat die Dekaloog nie in die Vroeë Kerk en gedurende die vroeë Middeleeue in die erediens aangetref word nie (Barnard 1981:544).

Voortvloeiend hieruit word die vraag na wat vandag die riglyn vir die Christen se etiek is dikwels sonder enige huiwering beantwoord met verwysing na die Dekaloog.

Vir gelowiges wat glo dat gereformeerdheid juis semper reformanda beteken, moet die geldigheid van hierdie aannames getoets word. Dit gaan egter oor meer. Vir die

1.Met federale teologie of federalisme word in hierdie artikel die onderskeibare teologiese stroming bedoel wat vanaf Bullinger deur Ursinus en Olevianus teologiese stroming bedoel wat nagespeur kan word. Federale Calvinisme of Westminster teologie word as die ontwikkelde vorm van gereformeerde teologie gesien wat wydverspreid sedert die sewentiende eeu en verder voorkom. Dit moet van Calvinisme onderskei word, bedoelende die tradisie in die Calvyn - Beza - Hoë Calvinistiese lyn van Genève kerk in Suid-Afrika is die vraag na die riglyn vir etiese optrede meer as 'n blote akademiese vraag. Ons bevind onsself in 'n samelewing waar rassehaat steeds onder die oppervlak broei. Die beskadiging van kultuurhistoriese herinneringe, vreemdelingehaat en onverantwoordelike uitsprake van politici bring hierdie onderliggende haat en spanning weer na vore. Ek is oortuig dat die kerk hierop kan en moet antwoord, nie met die Tora as riglyn nie, maar met die wet van Christus.

Daag Galasiërs 6:2, naamlik 'Dra mekaar se laste en vervul so die wet van Christus', die geldigheid van die gebruik van die Tora vir gelowiges se beoefening van etiek na die koms, lewe, sterwe en opstanding van Christus, uit? Dit is die vraag wat nou hanteer moet word om uiteindelik aan te dui dat Jesus nie net 'n sogenaamde sedewet nie, maar die Tora as geheel, oorgeneem het. Dit het diepgaande implikasies vir die etiek van gelowiges wêreldwyd en spesifiek vir die kerk in Suid-Afrika.

Dit is belangrik om te begryp dat die titel van hierdie artikel nie verstaan moet word asof Galasiërs 6:2 die allesomvattende antwoord sou wees op die vraag na die Christen en etiek en selfs die Christen en die wet nie. Die hantering van Galasiërs 6:2 is gemik om die skeeftrekking van federalisme betreffende die Tora (die wet van Moses) as riglyn vir die Christen se etiese lewe aan die kaak te stel. Dit is die vraagstelling wat nou teen die agtergrond van hierdie spesifieke gerigtheid verstaan en hanteer moet word.

\section{Die belang van die Jesus-tradisie in Paulus}

In die beantwoording van hierdie vraag is dit van groot nut om van die uiters insiggewende en deurslaggewende navorsing deur Seyoon Kim, kennis te neem in verband met die Jesus-tradisie, of die sogenaamde 'Jesus sayings', in Paulus. Kim (2002:259-269) dui op oortuigende wyse aan dat daar oor die 25 gevalle is waar Paulus verseker of moontlik, verwysings maak na, of sinspeel op 'n uitspraak van Jesus. Verder tabelleer hy oor die 40 moontlike eggo's van 'n uitspraak. Hy kom tot die gevolgtrekking dat daar 'n besondere kontinuilteit is tussen Jesus se lering wat rondom die koninkryk van God en Paulus se teologie as 'n geheel sentreer (Kim 2002:270-273). Die vervanging van Jesus se evangelie van die koninkryk van God met die Apostoliese evangelie van die dood en opstanding van Jesus is logies noodsaaklik gemaak deur die verlossing wat in Jesus se prediking van die koninkryk beloof is en wat nou in sy dood en opstanding gerealiseer het. Volgens Kim (2002:289) word die teologiese kontinuitteit tussen Jesus en Paulus verder ondersteun deur Paulus se konkrete eggo's van die 'koninkryk van God' en 'Abba', asook sy lering oor die wet, die tempel en die eskatologie, Jesus se verwelkoming van sondaars, sowel as ander aspekte van sy houding en gedrag soos die afswering van ' $n$ mens se voorregte en nederige diens.

Volgens Kim (2002:299) moet die feit dat die verwysings na Jesus se uitsprake relatief min en dikwels nie so eksplisiet is 
nie, verstaan word in die lig van die feit dat vir Paulus, asook vir die post-opstandingskerk as 'n geheel, Jesus betekenisvol was - nie primêr as 'n leraar nie, maar as die Christus wat gesterf en opgestaan het. Paulus konsentreer dus op die Christus-gebeure en hy kan nie met ' $n$ rabbi of Hellenistiese filosoof vergelyk word wat sy leraar ywerig aanhaal nie. Soos Kim (2002:290) dit stel: 'He (Paulus) seldom cited Jesus' sayings explicitly, but represented them, echoing them in his own language.'

Hierdie insigte is uiters belangrik, want dit beteken dat 'n mens kan verwag dat Paulus se siening van die voortgaande geldigheid van die wet (Tora) in noue ooreenstemming sal wees met dié van Jesus soos dit in Matteus 5:17 na vore kom. Verder kan verwag word dat die Christus-gebeure van die kruis en die opstanding 'n belangrike rol in Paulus se siening van die Tora sal speel.

\section{Rabbiniese getuienis en Matteus 5}

Allison (1993:187) toon aan dat die Hebreeuse ekwivalent van Galasiërs 6:3 se 'wet van Christus', naamlik die woorde, 'Tora van die Messias', in Mid Qoh.11:8 voorkom. Hieruit blyk dit dat pre-Christen Judaïsme reeds van 'n Messiaanse Tora gepraat het.

Dat Jesus die rol van Israel in Matteus se denke oorneem, is duidelik wanneer Jesus uit Egipte geroep word (Matt 2:15), deur die water gaan (Matt 3) en in die woestyn versoek word soos Israel (Matt 4). Dat Jesus Satan uit Deuteronomeum die verbondsboek antwoord, is natuurlik ook insiggewend.

Dit is nog meer ooglopend dat Jesus homself in Matteus 5 terselfdertyd met Moses kontrasteer in die lig van die makroteks, die groter konteks. Matteus 5:1-2 is spesifiek belangrik waar die Sinai-tipologie die leser lei om 'n nuwe openbaring deur die nuwe Moses te antisipeer (Poythress 1991:252). Aan hierdie verwagting word spesifiek in Matteus 5:21-48 voldoen waar Jesus die Dekaloog twee maal 'uitbrei' (Matt 5:21-30). Hoofstuk 5:21-48 gaan dus met die Mosestipologie voort, naamlik dat Jesus die nuwe wetgewer is.

Daar moet onthou word dat Mosaïese karaktertrekke in Judaïsme na latere wetgewers en leraars transmigreer. Hier dink 'n mens byvoorbeeld aan Esegiël en Hillel. In 4 Ezra ontvang die Skrifgeleerde byvoorbeeld die ou openbaring van Sinai plus nog addisionele, nuwe openbaring; die Mosestipologie word hier uitgebrei.

In soverre Matteus dus die klem laat val op die feit dat sy leraar en openbaarder ' $n$ nuwe Moses is, is hy slegs konvensioneel. Die feit dat die spreker van die Bergrede meer is, is egter belangrik. Hy is die Messias. Met ander woorde, $\mathrm{Hy}$ is die vervulling van die eskatologiese verwagting; die kulminasie van Israel se geskiedenis. Die vraag is nou of 'n mens van 'n 'messiaanse' Tora moet praat. Saam met Allison (1993:185) wil 'n mens positief antwoord: Jesus is die Moses-agtige Messias wat die eskatologiese wil van God van 'n berg afkondig, tipologies gelykstaande aan Sinai. Natuurlik moet toegegee word dat 'n mens nie met die benaming 'messiaanse Tora' kan aanneem dat die 'messiaanse Tora' 'n goed gedefinieerde konsep in Matteus se wêreld is nie; ook nie dat die gebruik daarvan vry van twyfelagtigheid is nie. Terselfdertyd is dit wel so dat 'n ondersoek van sekere tekste die feit van 'n messiaanse Tora in Matteus ondersteun.

Matteus assosieer waarskynlik Jesus se amp as leraar met sy status as Messias. Dit volg uit die verwagting waarvan daar in baie tekste sprake is uit verskillende tye en plekke. Volgens hierdie tekste sal die Messias en moontlik een of ander eskatologiese figuur eskatologiese instruksie bring.

Allison (1993:187) toon verder aan dat die rabbiniese bronne getuienis lewer tot ' $n$ verskeidenheid oortuigings omtrent die lot van die Tora in die Messiaanse era of die era wat sal kom. Daar is ' $n$ hele spektrum: van diegene wat meen dit sal dieselfde bly, tot diegene wat meen dat daar 'n nuwe Tora sal wees. Natuurlik is die beredenering hier te twyfelagtig om tot enige gevolgtrekkings te kom. Tog is dit duidelik dat Paulus, wat hy ook al daarmee bedoel het, na Jesus kan verwys as een wat sy eie nomos het.

Dit is veelseggend dat drie van die voorspellings van Jeremia 31:31-34 ' $n$ vervulling in Matteus vind: Jesus die Messias stel 'n nuwe verbond in (Matt 26:28), lê klem op die interne dimensies van die gebooie (Matt 5:21 e.v.) en Hy gee sy lewe as losprys vir baie (Matt 20:28; 26:28). Verder neem baie kommentatore in Matteus 26:28 ('dit is die bloed van die nuwe verbond ... tot die vergifnis van sonde') 'n sinspeling waar op Jeremia 31:31 en verkondig op so 'n wyse die realisering van Jeremia se woorde in Jesus se dade (Luk 22:17; 1 Kor 11:25).

Die versoeking is groot om die aanname te maak dat Matteus 1-5 Jesus as die nuwe wetgewer, die eskatologiese interpreteerder van die Tora, voorhou. Dit is hierdie Tora wat Jesus inderdaad kom instel het, wat Hyself in werklikheid beliggaam. Dit is ook hierdie Tora, dus Jesus self, wat die vervulde Tora van Matteus 5-17 is. Hierdie Tora is nie 'n vernietiging van die ou Tora nie, maar die vervulling daarvan tot 'n ongekende volheid.

Sonder twyfel kan hierdie opmerkings ' $n$ aanduiding wees dat Paulus op ' $n$ bekende tradisie steun en dit dan met sy eie inhoud verder vul en uitbou. Met hierdie opmerkings in gedagte kan daar nou intensief na Galasiërs 6:2 gekyk word. Wanneer hierdie uitspraak ontleed word, is dit van die uiterste belang om hermeneuties getrou aan Paulus se bedoeling in die hele brief te wees. Uitsprake oor die betekenis van Galasiërs 6:2 wat uiteindelik in stryd is met Paulus se brief in die geheel, kan nie op grond van dogmatiese oortuigings gelewer word nie. Inteendeel, die vraag na die hermeneutiese sleutel tot die verstaan van Galasiërs is in hierdie verband ononderhandelbaar.

\section{Galasiërs 6:11-18 as die hermeneutiese sleutel tot Galasiërs}

Dit ly geen twyfel nie dat Jeffrey Weima met sy 'epistolary analysis'-benadering, baanbrekerswerk gedoen het om die 
Pauliniese briewe se hermeneutiese sleutels te identifiseer. Hy doen dit aan die hand van Paulus se gebruik van die antieke briefvorm en die wyse waarop Paulus hierdie briefvorm gebruik en verander om sy spesifieke boodskap te beklemtoon. Nie net die begin van 'n brief nie, maar ook die einde van 'n brief, wat dikwels in die verlede geïgnoreer is, blyk van deurslaggewende betekenis te wees in die verstaan van Paulus se geskrifte.

Wat die Galasiërs-brief betref, is die slot deurslaggewend vir ons verstaan van waaroor die brief gaan en ook vir die verstaan van Galasiërs 6:2. Hierdie briefeinde bevat 'n reeks skerp kontraste tussen Paulus en sy opponente. Weima (1993:93-94) dui aan dat die kernsaak waaroor dit in hierdie briefeinde gaan en wat die waterskeiding tussen Paulus en sy opponente vorm, die kruis van Jesus Christus is.

Wanneer Galasiërs 6:2 op die tafel kom, moet dus verwag word dat hierdie sentrale saak, naamlik die kruis van Christus, ook hier van deurslaggewende belang is - dit terwyl Paulus by Jesus se siening van die vervulling van die wet binne die koninkryk, te wete die nuwe verbond, aansluit. Die nuwe verbond is egter vir Paulus ondenkbaar sonder die Gees. Wright (2004:267) dui oortuigend aan dat dit by Paulus altyd Christus en die Gees saam is wat die volk van God herdefinieer.

In die vraag na die betekenis van die 'wet van Christus' moet bogenoemde elemente op 'n logiese wyse met mekaar in verband gebring word.

\section{Wat is die wet van Christus dus?}

Inleidend moet kortliks kennis geneem word van Betz se siening dat die frase, 'wet van Christus' op 'n polemiese wyse in Galasiërs 6:2 gebruik word. Volgens Betz (1979:298-301) is dit vreemd dat die uitdrukking deur Paulus gebruik word en gee daarom te kenne dat Paulus dit geleen het om sy opponente te weerlê. Dit is egter hoegenaamd nie duidelik dat die frase polemies gebruik word nie, veral wanneer in gedagte gehou word dat Paulus dit in die paranetiese gedeelte van sy brief gebruik sonder die voorsiening van enige noemenswaardige aanduiding dat die frase as 'n reaksie op sy opponente verstaan moet word.

Die ooreenkoms tussen Galasiërs 6:2 en Galasiërs 5:14 is opvallend. Dit wil voorkom asof Paulus juis die betekenis van 'vervulling van die wet' wil verhelder deur die voorwerp van vervulling te verander van 'die hele wet' (Gal 5:14) na 'die wet van Christus' (Gal 6:2). Die onmiddellike konteks van die verwysing na die wet van Christus vestig 'n treffende kontras tussen die wet van Moses en die wet van Christus. Die wet van Christus word vervul deur sondaars te herstel en hulle laste te dra (Gal 6:1-2), terwyl die doel van die Mosaïese wet is om 'oortredings uit te wys' (Gal 3:19). Paulus se hele brief aan die Galasiërs is vol illustrasies van maniere waarop die Tora gebruik is om sondaars van die kerk te skei, terwyl die doel van die wet van Christus daarenteen is om sondaars in die kerk te dien.
Ten spyte van die belangrike kontras tussen die wet van Moses en die wet van Christus in Galasiërs, is daar tog 'n treffende parallel tussen Paulus se aanhaling van die liefdesgebod uit die Tora (Gal 5:14) en sy verwysing na die wet van Christus (Gal 6:2). Albei 'wette' word deur gebooie om wedersydse diens te verrig, ingelei: 'Dien mekaar in liefde' (Gal 5:13) en 'dra mekaar se laste' (Gal 6:2). In albei gevalle word die term, vervul, gebruik om die resultaat van die wedersydse diens te beskryf. In die lig hiervan beweer sommiges dat so 'n noue verbintenis daarop dui dat die twee een en dieselfde is. Vervulling van die wet van Christus behels dus vervulling van die Tora.

So 'n eenvoudige gelykstelling werk egter nie in Galasiërs nie. Benewens dit wat nou reeds bespreek is omtrent die hermeneutiese sleutel tot die brief, wys Paulus ook dat ten minste sommige gebooie van die Tora - soos die voedselwette (Gal 2:14), die Sabbat- en feesregulasies (Gal 4:10) en die besnydenis (Gal 5:2-4) - slegs op Joodse Christene van toepassing is en nie op die heiden-Christene nie. Hy gaan voort om teen enige poging om die hele Tora te onderhou (Gal 5:3), te waarsku.

Ander navorsers interpreteer weer die verbintenis tussen die vervulling van die liefdesgebod van die Tora en die vervulling van die wet van Christus as 'n bewys dat slegs die gebod om lief te hê - losstaande van alle ander eksterne beginsels of direktiewe - die wet van Christus is (Fung 1988:286-289). Maar so 'n verstaan word weerlê deur die feit dat Paulus (sowel as Jesus) die liefdesgebod definieer en toepas in terme van eksterne beginsels en spesifieke riglyne. Paulus beklemtoon sekere spesifieke instruksies vir die kerk in Galasiers 6:1-10).

Nog ander meen dat die liefdesgebod soos deur die lering en voorbeeld van Jesus gedefinieer en geillustreer, die 'wet van Christus' is (Davies 1980:142-144). Hierdie interpretasie is waar, maar dit gaan nie ver genoeg nie. Dit skep die indruk dat Paulus bloot een stel voorskrifte, die Tora, met 'n nuwe stel regulasies, afgelei van die woorde en werke van Jesus, vervang.

Die probleem met so 'n perspektief is dat dit die sentraliteit van die kruis van Christus en die opstanding van Christus deur sy Gees, in die lewe en etiese lering van Paulus mis. Jesus leer die liefdesgebod van Levitikus 19:18 deur sy woorde en optrede, maar Paulus fokus nie op die woorde of handelinge van Jesus nie. Daar is nie 'n eksplisiete verwysing in Galasiërs na enigiets wat Jesus ooit gesê of gedoen het gedurende die loop van sy bediening nie. Paulus se fokus is eerder op die kruis van Christus en sy verlossingswerk aan daardie kruis; op die feit dat Christus ons liefgehad het en homself vir sonde gegee het (Gal 1:4; 2:20) deur self 'n vloek vir ons te word (Gal 3:13) om ons sodoende vry te maak van die las van die juk van slawerny (Gal 5:1). Paulus wil die 'dwase' Galasiërs terugbring na sy dramatiese voorstelling van Christus die gekruisigde (Gal 3:1).

In die lig hiervan moet tot die gevolgtrekking gekom word dat vir Paulus Christus die gekruisigde, die wet van Christus is 
(Hansen 1997:232) en die kruis die standaard is vir die gee van jouself en selfopofferende liefde. Dit is die kruis wat by uitnemendheid die maatstaf van liefde is. Enige definisie van die wet van Christus wat die kruis uit die oog verloor, verloor die kern van Paulus se etiek (Hansen 1997:232). Diegene wat deur die Gees gelei word, sal dieselfde selfopofferende liefde van Christus openbaar (Gal 5:22-23). Net soos Hy sal hulle sondaars herstel deur hulle laste te dra (Gal 6:1-2).

Dit is interessant om daarop te let dat Hofius tot dieselfde slotsom kom. Hy verstaan die 'wet van Christus' asof gegrond in die Knegliedere van Jesaja 42:1-4 en 52:13-53:12. Die Kneg as die sondedraende plaasvervanger dra die laste; die sondes van die sondaars. Dit is volgens hom parallel aan Galasiërs 6:2 waar die een wat die wet van Christus vervul, die laste van andere dra. In die lig van Galasiërs 6:1, is Hofius (1983:262286) van mening dat die laste die 'sonde en smarte' is. Diegene wat die reddende krag van God in die evangelie beleef, word sodanig daardeur aangegryp dat hulle die evangelie in hulle verhouding met ander gelowiges beliggaam.

Aansluitend by hierdie siening, is dié van Hays. Hy reken ook dat om volgens die wet van Christus te lewe, beteken om in ooreenstemming met die patroon te leef wat deur Jesus duidelik gemaak is. Christus se gee van Homself aan die kruis word die paradigma vir alle mense (Hays 1987:268290). Sulke liefde bring die liefde van Christus tot uitdrukking en vervul sodoende die wet van Christus. Sodanige Christusliefde vervul die hele bedoeling van die Tora, en kan in die liefdesgebod van Levitikus 19:18 opgesom word (Hansen 1997:232).

Dit bring ' $n$ mens by die feit dat hierdie wet van Christus, wat ook Christus die gekruisigde is, die wet onder die nuwe verbond is wat die nuwe volk van God se riglyn binne die nuwe verbond vorm. 'n Riglyn wat as sodanig nie die ou Tora vernietig nie, maar juis tot sy volheid vul en sy oorspronklike bedoeling, wat nooit nagekom kon word nie, 'n moontlikheid maak onder die 'nuwe Israel' van God. Hierdie nuwe Israel toon juis sy andersheid deur die 'kruisliefde'.

In gedeeltes soos Eksodus 19:5-6 en in die tradisionele Judaïsme is die doel van die nakoming van God se gebooie om te verseker dat God se kosbare mense in hulle heiligheid onderskeibaar is. In die lig hiervan is Paulus se saak teen die nakoming van die wet vir baie Joodse Christene van sy tyd sekerlik niks anders nie as 'n skewe teologie en praktiese, uiters gevaarlike raad. Die rede is dat dit voorgekom het asof dit sonder enige leiding vir, of enige eksterne beperking gelê het op elke dag se lewe. Indien die wet, wat verlossing betref, irrelevant is soos Paulus duidelik geglo het, is die weg natuurlik oop vir 'n etiese antinomie en selfbevrediging sonder perke. Paulus dui ook aan dat dit presies die aanklag is wat teen hom gelê is (Rom 3:8 en 6:1, 15).

Dit wil voorkom asof die Christene in Galasië bekommerd was oor dieselfde 'tekortkominge' in Paulus se verstaan van die wet. Hulle het duidelik die Tora gesien as sowel die middel waardeur iemand ingewy is onder Abraham se erfgename, en ook die standaard waarvolgens etiese gedrag hanteer en gereguleer moes word. Paulus se brief hanteer hierdie saak aanvanklik in verhouding tot die getroue lewe van Christus wat in die lewe van Christene beliggaam is. In Galasiërs 2:19 maak Paulus dus daarop aanspraak dat Christus in hom leef - 'n gedagte wat hy verder in vers 20 ontwikkel in terme van die getrouheid van Christus ( $\dot{\varepsilon} v \pi i ́ \sigma \tau \varepsilon 1$

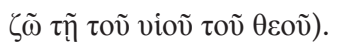

In Paulus se verstaan, word die gelowige se daaglikse lewe nie deur die onderhouding van wettiese verpligtings gekenmerk nie, en ook nie deur wetteloosheid nie, maar deur die verbondsgetrouheid van die Seun van God wat in die gelowige uitgeleef word (Longnecker 1997:144). Paulus verduidelik die inhoud van Jesus se getrouheid (Gal 2:20) in terme van die Seun se liefde vir ander en die opoffering van Homself ter wille van hulle en tot hulle voordeel (Gal 1:4).

Paulus se etiek in Galasiërs ontwikkel vanuit hierdie Christologiese punt en in verhouding tot die Gees, wat as die Gees van Christus (Gal 4:6) geïdentifiseer word. Die Gees se aktiwiteit voed eienskappe binne die Christelike gemeenskap wat die karakter van Jesus uitbeeld. Dit is niks minder nie as dinamiese uitbreidings van die kwaliteite wat $\mathrm{Hy}$ in sy aardse lewe ten toon stel, maar spesifiek ook die liefde wat $\mathrm{Hy}$ aan die kruis bewys; liefde wat alle ander vorms van liefde oortref. Hierdie kruisliefde van Christus word nou ook deur gelowiges getoon in die dra van mekaar se laste.

Die Christologiese model van verbondsgetrouheid, wat in liefde en die gee van die self manifesteer (Gal 1:4; 2:20), is Paulus se paradigma vir 'n Christelike lewenstyl (Gal 5:2223). Hierdie Christus-gelykvormige karakter moet binne die korporatiewe lewe van gelowiges (Gal 4:19) gevorm word. Dit gebeur namate die lede 'beklee word met Christus' (Gal $3: 27)$, net soos 'n akteur die kleredrag van 'n ander aantrek sodat hy daardie persoon binne die konteks van die toneelstuk 'kan wees'. Binne hierdie vergelyking is die hele lewe die teater waarin Christene Christus beliggaam en uitbeeld deur middel van hulle Christus-gelykvormige karakter, wat 'n werklikheid word deur die Heilige Gees (Longnecker 1997:145).

Die verbondsgetrouheid van Christus tot aan die kruis, is die konteks waaruit die karakterkenmerke van die nuwe wêreldorde van Geesgedrewe liefde en die gee van die self ontstaan. Die hele vraag of dit tot wetteloosheid lei, word as 't ware deur Paulus in Galasiërs 5:13-14 beantwoord wanneer hy hierdie eskatologiese karakter beskryf as die manier waarop die wet vervul word. Diegene wat deur die Gees in liefde en diens aan ander wandel, vervul of 'voldoen aan die standaard' van die Mosaïese wet deur daardie Christusgelykvormige liefde, selfs sonder die nakoming van die wet se spesifieke voorskrifte (Rom 8:4; 13:8-10; Gal 6:2; vgl. Schreiner 1993:544).

Dit is sekerlik nodeloos om te beklemtoon dat hierdie wet van Christus die hele Tora oorneem en nie net die sogenaamde 
morele of sedewet nie. Wanneer Paulus in Galasiërs van die wet praat, verwys hy na die hele wet van Moses, die Tora, wat 430 jaar na Abraham gekom het (Gal 3:17). Die enigste twee uitsonderings is die volgende:

- Galasiërs 5:23: 'teen sulke dinge is daar geen wet nie', waar Paulus waarskynlik ook kan verwys na die Tora; en

- Galasiërs 4:21b waar Paulus duidelik na die Pentateug verwys. In sekerlik een van die mees resente, omvattende studies oor Paulus en die wet, dui Rosner (2013:40-43, 208) oortuigend aan dat Paulus nomos as 'n eenheid sien en hanteer.

Christus die gekruisigde neem dus nou die rol van die Tora oor. In hierdie nuwe Tora en die navolging daarvan, kan dit wat die Mosaïese Tora nooit kon vermag nie, tot vervulling kom. Dit gebeur in die liefdevolle diens van diegene wat deur die Gees van Christus tot gelykvormigheid aan die karakter van Christus getransformeer is. Hulle is die volk van die nuwe verbond. Die meer resente werk van Law (2012) sluit hierby aan waar hy tot die gevolgtrekking kom dat die nuwe verbond self die wet van Christus is.

Dit is daarom nie vreemd dat Paulus die term Israel van God

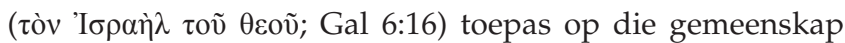
van dié wat in Christus is en waarin die Tora sy vervulling vind nie.

\section{Implikasies vir die etiek in die gereformeerde gemeentekonteks Begripsverheldering}

Wanneer daar oor die praktiese implikasies besin word wat hierdie artikel vir die etiek en etiese prediking inhou, is dit belangrik om te weet wat presies daarmee bedoel word. Met etiese prediking word prediking bedoel waarin daar gepoog word om lidmate in die lig van die Bybel te laat besin oor die etos wat hulle beoefen. Alle mense en alle lidmate het onbewustelik 'n etos waarvolgens hulle lewe. Dit is die beoefening van etiek. Etiese prediking het 'n verandering in die gedrag (etos) van mense ten doel.

Cilliers (1996:9) wys tereg daarop dat wettiese prediking deur 'n wanbegrip van die verhouding tussen wet en evangelie veroorsaak word. Anders gestel: 'n Mens moet verstaan dat daar 'n verskil tussen die etiek van die $\mathrm{Ou}$ Testament en die etiek van die Nuwe Testament is soos hierbo deur die bestudering van Galasiërs 6:2 aangetoon is.

\section{Etiek onder die Ou Verbond}

Die wet van Moses (Tora) mag nie van sy begronding in die verbondsgeskiedenis losgemaak word nie. Dit was nie 'n goddelike wetgewing wat onafhanklik van God se groot handeling van verlossing in die Eksodus is nie. Die wet van Moses het as 't ware uit die Eksodusgeskiedenis gegroei. Hierdie groot handeling van God het van die Israeliete gedrag vereis wat 'n toepaslike reaksie op sy verlossing sou wees. Die totale etiese sisteem van die Ou Testament is deur die Eksodusgebeure gestruktureer en gekleur. Die karakter van die Eksodusgebeure het die manier waarop Israel verplig was om te leef, bepaal.

Die Dekaloog, ook genoem die 'woorde van die verbond' (Eks 34:28), word deur 'n stelling omtrent God se verlossing (Eks 20:2) voorafgegaan. Juis omdat die magtige Skepper, die Vader, Man, Koning en Bondgenoot van sy volk geword het deur middel van 'n handeling van vrye guns en liefde, en omdat Hy hulle Beskermer is en die Waarborg dat Israel alles sal hê ('Ek is ... jou God'), is daar 'n geïmpliseerde daarom (Eks 20:3). Deuteronomium is vol voorbeelde van hierdie indikatief-imperatiefverhouding (Deut 11:7, 8; vgl. 6:20-24; 7:7-11; 10:17-19; 27:9, 10).

In die $\mathrm{Ou}$ Testament is die essensie van aanbidding die onthou, herhaling en oordenking van die magtige handelinge van God, spesifiek in die Eksodusverhaal (Rig 5:11; Ps 66; 78; 105; 106; 111:4). Sonde was altyd 'n uitdrukking van 'n vergeetagtigheid ten opsigte van wat God gedoen het. Vir die Ou-Testamentiese heilige was die lewe 'n dankbare viering van die eksodus. Sy godsdiens was een van herinnering en dankbaarheid.

Die wet van Moses was niks anders nie as die definiëring van konkrete handelinge waardeur die magtige dade van God onthou kon word en die Israeliet sy dankbaarheid vir die insluiting in daardie heilige geskiedenis kon uitdruk. Die eksodus het bepaal hoe Israel in elke saak moes optree.

\section{Etiek onder die Nuwe Verbond}

Die Nuwe-Testamentiese etiek het dieselfde karakter as die OuTestamentiese etiek aangesien dit uit die verlossingsgeskiedenis voortvloei en deur daardie geskiedenis gestruktureer en gekleur word. Hierin lê die kontinuïteit tussen die etiek van die Ou Testament en dié van die Nuwe Testament. Aangesien albei in 'n groot verlossingshandeling gegrond is, vereis albei 'n etiek van dankbaarheid en 'n lewe van geloof en liefde.

Tog is daar ook diskontinuïteit tussen die etiek van die Ou en die Nuwe Testament. Die Nuwe Testament is nuut aangesien dit 'n nuwe historiese verwysingspunt het. In die dood en opstanding van Jesus het die grootste verlossingshandeling van alle verlossingshandelinge plaasgevind. Hier word die totale geskiedenis van die Ou Testament in een magtige daad van verlossing opgesom. In Christus vind die nuwe skepping en die nuwe eksodus van die menslike geskiedenis eens en vir altyd plaas.

Net soos die wet van Moses die morele imperatiewe bevat wat uit die Eksodus voortvloei - die Sinai-gebeure - so beliggaam die 'wet van Christus' die morele imperatiewe wat uit die lewe, dood en opstanding van Christus voortvloei - die Christusgebeure. Die manier waarop die Christelike gemeenskap opgeroep word om te lewe, is gestruktureer, bepaal en gekleur deur die Christusgebeure.

In die Nuwe Testament is die imperatiewe gegrond in die herhaling van God se groot daad in Christus. Die verwysing 
na 'soos Christus' word ook meermale gebruik om gelowiges na 'n selfopofferende liefdevolle optrede op te roep. Liefde kry 'n nuwe historiese verwysingspunt, naamlik liefde wat deur die kruis van Christus gedefinieer word.

Die gevaar bestaan dat gereformeerdes onder die invloed van federalisme as 't ware vir genade na die Christusgebeure kan gaan, maar na Moses vir etiek terugkeer. Laasgenoemde gedrag sê ten diepste dat Christus ons geloof moet struktureer, maar Moses ons etiek. Daar vind dus 'n skeiding plaas in die dinamiese verhouding tussen die historiese verlossingsgebeure en die etiek wat daaruit voortvloei. Die Dekaloog word dan sonder meer die riglyn vir die dankbaarheidslewe van die gelowige. Omdat die Dekaloog uit die verlossingsgeskiedenis van die Eksodus voortvloei, is dit nie genoegsaam om die aard van die lewe onder die nuwe verbond te reguleer nie.

Hierin skuil egter 'n nog groter gevaar. Wanneer die Westminster Confession se hantering van die Sabbat as lakmoes gebruik word vir die wyse waarop hulle die funksionering van die sedewet in die Christen se lewe sien, kry 'n mens baie sterk die indruk dat die model en beeld waarna beweeg moet word, nie Christus is nie, maar die 'law of universal obedience' (par. 19:1) wat reeds in Adam se hart geskryf is en steeds '... the perfect rule of righteousness after the Fall' (par. 19:2) is (vgl. Philip 1984). Dit verskil egter heeltemal van Calvyn wat Christus as die model en beeld sien waartoe God die mens wil verander (Calvyn 1984: Inst. 3.6.3).

Meer kommerwekkend is die feit dat as 'n gereformeerde, 'n mens aanvoel dat hier ten diepste 'n verdraaiing van die skopus en klem van die totale Skrifboodskap omtrent Jesus Christus as die Alfa en die Omega is. Hierdie skopus en klem is vanuit 'n dogmatiese hoek reeds uiters suksesvol deur Adrio König in Jesus die laaste (1985) beredeneer. König toon aan dat Jesus God se hoogste skeppingsdoel is (König 1985:28-38) en dat Hy hierdie doel vir ons (König 1985:89126), in ons (König 1985:136-233) en met ons bereik (König 1985:243-206). As Ou-Testamentikus sluit Christopher Wright (2014) se meer resente werk hierby aan wanneer hy aantoon dat Jesus die beliggaming van die Ou-Testamentiese wet, waardes, sending en verhaal is. Vanuit NuweTestamentiese kant het N.T. Wright 2004:266-267) met sy uiters deeglike eksegese van Paulus, enige twyfel uit die weg geruim dat Jesus presies die rol van die Tora in Paulus se teologiese verstaan ingeneem het.

'n Mens kan dus met vrymoedigheid beklemtoon dat die Nuwe Testament daarom nie die gees-gedoopte gemeenskap na Moses terugstuur om hulle plig te leer nie. Nêrens word die ná-Pinkstergemeenskap vermaan om die Tora as riglyn vir hulle lewe te bestudeer nie. Paulus redeneer deurgaans in sy briewe vanaf die evangeliegebeure na die etiek. Hy wys hoe die verlossingshandeling in Christus moet bepaal hoe 'n mens jou in alle menslike verhoudings moet gedra (bv. 1 Kor 6:15-20). Dit is insiggewend dat Paulus wel na Christene verwys wat die wet 'vervul', maar nooit sê dat gelowiges die wet moet 'hou' of 'gehoorsaam' nie. Gelowiges 'gehoorsaam' die evangelie (Rosner 2013:88).
Wanneer Petrus en sy geselle in Antiochië fouteer en in die openbaar tereggewys moet word, verdoem Paulus hulle gedrag ook nie op grond van die wet van Moses nie. Hy staan hulle teë op grond van die feit dat 'hulle nie reguit loop volgens die waarheid van die evangelie nie' (Gal 2:14). Paulus haal die Ou-Testamentiese gebooie slegs in drie of vier geïsoleerde gevalle aan. Waar hy dit wel doen, is dit nie die basis van sy etiese appèl nie, maar 'n sekondêre appèl - en selfs dán gebruik hy die wet van Moses met groot profetiese vryheid (vgl. 1 Kor 9:9). 'n Stelling uit die wet het nie vir Paulus dieselfde absolute outoriteit as wat dit vir die Judaïsme het nie. Rosner (2013:218) wys daarop dat Paulus dit hertoepas as profesie en wysheid.

Aangesien die wet van Moses ons tot heiligheid en dankbaarheid teenoor God en 'n lewe van geloof en liefde oproep, leef die gees van die ou wet steeds onder die nuwe bedeling voort. Die tydlose etiese beginsels in die wet van Moses leef onder die 'wet van Christus'voort. As deel van ' $n$ verbond (Deut 4:13), het die Dekaloog egter tot 'n einde gekom (Heb 8:13) aangesien daardie verbond met die superieure bediening van die Gees vervang is (2 Kor 3:4-11).

Vir die prediking is hierdie klem van die uiterste belang. Die solus Christus van die Hervormers kan nie net vir die leerstelling van geloof en regverdigmaking deur geloof normatief wees nie. Dit moet ook die riglyn vir etiese prediking wees, aangesien solus Christus ook totus Christus beteken; dit wil sê, die hele Christus vir die hele lewe. Gelowiges moet opgeroep word om as ' $t$ ware Jesus in hulle omgang en kontak met die buitewêreld te wees en te word. Die 'gestuur wees' in die wêreld soos Jesus, om iets van die koninkryk van God te laat sigbaar word, soos Jesus, moet prominent in die prediking wees. Daar moet altyd onhou word dat God se naderende koninkryk in Jesus die praktiese vorm is van die messiaanse vervulling van byvoorbeeld Israel se wette omtrent die Sabbatsjaar en die Jubeljaar (Moltmann 1990:121). Hierdie wette vorm 'n onlosmaaklike eenheid met die res van die Tora, en soos Goldsworthy (2000:163-164) tereg opmerk, gaan dit weer geheel en al oor die strukturering van 'n lewe onder die heerskappy van die Groot Koning!

\section{Vryheid en liefde}

Paulus sê aan die Galasiërs dat enigeen wat aan die wet van Moses onderworpe is, niks anders as 'n slaaf is nie. Die onderhouding van 'dae en maande en tye en jare' is 'diensbaarheid onder die eerste beginsels van die wêreld' (vgl. Gal 4:1-10). Die apostel doen 'n beroep op sy bekeerlinge wat na hierdie dinge wil terugkeer: 'Staan dan vas in die vryheid waarmee Christus ons vrygemaak het, en laat julle nie weer onder die juk van diensbaarheid bring nie' (Gal 5:11).

God wou gehad het dat Israel oorvloedig en vrygewig moes wees in dit wat God aan hulle gegee het, en Hom as die Gewer en Besitter van alles sou erken. Om hulle hierin te help, het Hy hulle 'kinderlike' opvoedingsregulasies gegee. 
Hierdie regulasies was nie die regte wet agter die wet nie. Nog minder was dit permanent van aard. Dit was tydelike regulasies wat op Israel afgedruk is, totdat Christus sou kom (Gal 3:23-24). In die Nuwe Testament verander God nie die werklike wet agter die Mosaïese regulasies nie. Die Nuwe Testament wil nog meer hê dat God se mense vrygewig met sy gawes moet wees en dat hulle sy aanspraak op alles wat hulle is en het, sal raaksien. Die Nuwe Testament gee egter nie regulasies oor tiendes, offerandes en tye en plekke van aanbidding nie.

Natuurlik het die kerk steeds tye en plekke van aanbidding nodig. Gees het steeds vorm nodig - dit wil sê, waar daar geloof is, sal daar goeie werke wees; waar daar 'n gemeente is, sal daar regering en orde wees; waar daar evangelie is, sal daar sakramente wees. Waar die wet van Moses egter spesifieke voorskrifte in verband met die vorm gee, het die Nuwe-Testamentiese gemeenskap baie meer vryheid. Hierdie vryheid wat in die tydperk van die wet van Christus bestaan het, moet egter altyd in die lig van liefde verstaan word. Sonder hierdie klem sal die gemeente nie 'n voorstelling van Jesus self aan die wêreld wees nie. Trouens, Christelike vryheid is nie vryheid om weer die wet na te kom nie, maar dit is die deelname in Christus se outoriteit binne die skeppingsorde (O'Donovan 1994:101 e.v.). Dit is daardie outoriteit waarvolgens ons nie meer slawe is nie, maar kinders van God. Kortom beteken Christelike vryheid dus dat die toepaslike patroon van vrye respons tot die objektiewe realiteit, deur die Gees gevorm en tot uitdrukking gebring word.

Paulus beskryf hierdie respons in algemene terme as liefde. Liefde is die omvattende vorm van Christelike etiek; die vorm van menslike deelname in die geskape orde. Dit is self georden en gevorm in ooreenstemming met die orde wat dit in sy voorwerp ontdek. Substantiewe Christen-etiek het die taak om hierdie ordening van liefde na te spoor. Hierdie liefde is dieselfde liefde wat Jesus beoefen het. In die etiese prediking, ook hier in Suid-Afrika, is dit dus van die allergrootste belang dat hierdie verband tussen Gees, vryheid en liefde gepredik word.

\section{Katolisiteit en ekumenisiteit}

Die wet van Moses is kulties. Alhoewel dit tydlose etiese beginsels bevat, is dit in 'n kultiese kleed geklee. Die kultiese eiesoortigheid van die Mosaïese Tora het 'n skeidsmuur gevorm wat die heidene as 't ware uitgehou het. Christus het juis hierdie skeidsmuur afgebreek (Ef 2:14, 15). Onder die wet van Christus gaan dit dus nie meer oor 'n afskeiding van die buitewêreld om sodoende heilig te bly nie, maar dit gaan juis daaroor om die onheilige met die heilige binne te dring en so die onheilige te omvorm. Daar is ook nie meer net sekere heilige dae en tye wat beskerm moet word nie, maar alle dae, tye en plekke moet binnegedring en heilig gemaak word.

Samehangend met die voorafgaande moet onthou word dat die wet van Christus mense verenig en nie verdeel nie. Die
Tora onder Moses het mense eenkant gehou en sodoende 'n skeiding in die mensdom veroorsaak. Hierdie benadering mag geen rol in die internasionale Christelike gemeenskap speel nie. Die middelmuur van skeiding is afgebreek. Hierdie waarheid is uiters relevant vir die gees van vreemdelingehaat wat tans in Suid-Afrika heers.

Paulus waarsku Titus teen Joodse Christene (Tit 1:10-14) wat die wet gebruik om allerlei 'twis en stryery' onder Christene te veroorsaak (Tit 3:9; vgl. 1 Tim 1:6, 7). In die prediking moet baie aandag aan hierdie aspek gegee word; die prediking van die wet van Christus moet eenheid bevorder! Die relevansie hiervan vir die kerk in Suid-Afrika is ooglopend vir elkeen wat die gebeure rondom die Belhar Belydenis gevolg het.

\section{Die liturgie}

In die lig van hierdie studie en veral die implikasies soos dit beklemtoon is, moet daar daarom deeglik aan die liturgie aandag geskenk word. Die lees van die wet met die sondebelydenis wat daarop volg, kan nie meer onnadenkend toegepas word nie. Die huidige gebruik in die meerderheid gereformeerde denominasies kommunikeer onteenseglik dat hulle steeds onder die 'wet van Moses' staan. Daar moet deeglik tot op Sinodale vlak besin word hoe die liturgie daar moet uitsien noudat die wet van Christus die rol van die Tora oorgeneem het.

\section{Slot}

Jean-Luc Marion (1991:2) vermaan wyslik: 'One must obtain forgiveness for every essay in theology.'

Wie is ons as Christene? Blote sterflinge wat geneig is om te dwaal en die waarheid in ongeregtigheid te onderdruk. Wie is ons om oor God te praat? Tog is dit so dat stilbly van ons kant af ' $n$ weiering is om God, wat met ons in sy Tora praat, aan die woord te stel. Juis daarom poog hierdie artikel om weg te bly van 'n blote sistematies teologiese bespreking en 'n eksegetiese studie te doen.

Dit is die outeur se diepste versugting dat die etiek van gelowiges wêreldwyd en spesifiek die kerk in Suid-Afrika, deur die wet van Christus gevorm sal word. Dit is juis hierdie wet van Christus wat nodig is om ook in Suid-Afrika soos Jesus grense oor te steek. Anders gestel, hierdie wet kan vir ons 'n koninkryksingesteldheid gee wat die grense van ras, kleur, kultuur en geskiedenis oorsteek. Dit is juis omdat Jesus homself gesien het as die Een wat die koninkryk van God ingelui het, dat Hy buite die grense van Israel kon beweeg. Die Tora was daarom ook nie die beslissende beginsel in Jesus se optrede nie, maar wel die koninkryk van God. Dit beteken nie dat daar 'n diskrepansie tussen die koninkryk van God en die Tora is nie, maar eerder dat die ou Tora 'teruggedruk' word in verhouding tot God se koninkryk (Bosch 1992:35). Die nuwe Tora is nou rigtinggewend Galasiërs 6:2 is nou rigtinggewend.

Soli Deo Gloria! 


\section{Erkenning \\ Mededingende belange}

Die outeur verklaar dat hy geen finansiële of persoonlike verbintenis het met enige party wat hom nadelig kon beïnloed het in die skryf van hierdie artikel nie.

\section{Literatuurverwysings}

Allison, D.C., 1993, The new Moses: A Matthean typology, Fortress, Minneapolis. Barnard, A.C., 1981, Die erediens, NG-Kerkboekhandel, Pretoria.

Berkhof, L., 1988, Systematic theology, Banner of Truth, Edinburgh.

Betz, H.D., 1979, Galatians: A commentary on Paul's letter to the churches in Galatia, Fortress, Philadelphia.

Bosch, D.J., 1992, Transforming mission: Paradigm shifts in theology of mission, Orbis, Maryknoll.

Calvyn, J., 1984, Institusie van die Christelike godsdiens, Calvyn Jubuleum Boekefonds, Potchefstroom.

Cilliers, J., 1996, Die uitwissing van God op die kansel: Ontstellende bevindinge oo Suid-Afrikaanse prediking, Lux Verbi.BM, Kaapstad.

Davies, W.D., 1980, Paul and Rabbinic Judaism, Fortress, Philadelphia.

Fung, R.Y.K., 1988, The epistle to the Galatians, Eerdmans, Grand Rapids. (New International Commentary of the New Testament).

Goldsworthy, G., 2000, Preaching the whole Bible as Christian Scripture, InterVarsity, Leicester.

Hansen, W.G., 1997, 'Paul's conversion and his ethic of freedom in Galatians', in R.N Longnecker (ed.), The road from Damascus: The impact of Paul's conversion on his life, thought and ministry, pp. 230-232, Eerdmans, Grand Rapids.

Hays, R.B., 1987, 'Christology and ethics in Galatians: The law of Christ', Catholic Biblical Quarterly, 49, 268-290.

Hofius, O., 1983, 'Das Gesetz des Mose und das Gesetz Christi', Zeitschrift für Theologie und Kirche, 80, 262-286.
Irenaeus, 2006, 'Adversus Haereses: Early Church Fathers' in Sholar's Library: Gold, CD-ROM, Logos Bible Software.

Kim, S., 2002, Paul and the new perspective: Second thoughts on the origin of Paul's gospel, Eerdmans, Grand Rapids.

König, A., 1985, Jesus die laaste, 2e uitg., NG-Kerkboekhandel, Pretoria.

Law, G.R., 2012, 'The form of the new covenant in Matthew', American Theological Inquiry, 5:2.

Longnecker, R., 1997, 'Contours of covenant theology in the post-conversion Paul', in R.N. Longnecker (ed.), The road from Damascus: The impact of Paul's conversion on his life, thought and ministry, pp. 140-145, Eerdmans, Grand Rapids.

Marion, J.L., 1991, God without being: Hors-texte, University of Chicago Press, Chicago.

Moltmann, J., 1990, The way of Jesus Christ: Christology in messianic dimensions, SCM, London.

O'Donavan, O., 1994, Resurrection and moral order: An outline for evangelical ethics, Eerdmans, Grand Rapids.

Philip, J., 1984, The Westminster Confession of Faith: An Exposition, Clark, Edinburgh.

Poythress, V., 1991, The shadow of Christ in the law of Moses, Presbyterian \& Reformed, Philipsburg.

Rosner, B.S., 2013, 'Paul and the law: Keeping the commandments of God', InterVarsity, Downers Grove. (New Studies in Biblical Theology, 31).

Schreiner, T.R., 1993, 'Law of Christ' in R.P. Martin \& G.F. Reid (eds.), Dictionary of Paul and his letters, pp. 542-544, InterVarsity, Leicester.

Thomas van Aquino, 1947, Summa Theologica, Transl. of the Fathers of the English Dominican Province, Benziger Brothers, New York.

Torrance, J.B., 1994, 'The concept of federal theology: Was Calvin a federal theologian?', in W.H. Neuser (ed.), Calvinus Sacrae Scriptura Professor: Calvin as confessor of Holy Scripture, pp. 19-33, Eerdmans, Grand Rapids.

Weima, J.A.D., 1993, 'Galatians 6:11-18: A hermeneutical key to the Galatian letter', Calvin Theological Journal 28, 90-107.

Wright, C.J.H., 2014, Knowing Jesus through the Old Testament, 2nd edn., InterVarsity, Downers Grove.

Wright, N.T., 2004, The climax of the covenant, Fortress, Minneapolis. 